\title{
Cyprus Hydrocarbons: Lessons from the Nigerian Experience
}

\author{
Professor Kaniye S.A. Ebeku \\ LLB, LLM (LSE, LONDON), PhD (KENT, UK) \\ Pioneer Dean of Law, University of Port Harcourt, Nigeria; \\ Formerly, Head of Law Department, University of Nicosia, Cyprus. \\ Currently, Honourable Commissioner for Water Resources \& Rural \\ Development, Rivers State, Nigeria
}

Doi: 10.19044/esj.2018.v14n1p75 URL:http://dx.doi.org/10.19044/esj.2018.v14n1p75

\begin{abstract}
Hydrocarbons/oil is still the greatest source of energy in the world, although its importance is diminishing with the development of alternative/environment-friendly sources of energy such as wind-power and solar energy. For most oil-producing countries, hydrocarbons/oil revenue is a significant source of income. For instance, this is the case in Nigeria, whose economy depends heavily on oil revenue. Even so, natural resource wealth (hydrocarbons/oil, etc.) can also be a curse as it may cause poverty in the country, breed corruption, precipitate human rights abuses and other contradictions. This is the experience of some oil-producing countries such as Nigeria, Libya, Ecuador, and Algeria. The recent discovery of hydrocarbons in Cyprus is surely an important development for the country. However, given the negative experience of other resource-rich countries it is important to explore the possible lessons Cyprus may learn from such experience that could help her maintain a healthy economy when hydrocarbons revenue starts rolling in as projected, in 2022. This is the main objective of this paper and the Nigerian experience will be used as a case-study. Presently, the Cyprus economy without hydrocarbons revenue is strong and healthy; income is derived from diverse sources such as tourism, services and agriculture. This paper argues that Cyprus should learn from the experience of Nigeria and avoid abandoning other sources of revenue when it starts earning hydrocarbons revenue so that it would not suffer 'Dutch disease'. Moreover, from the experience of Nigeria, Cyprus should take precautionary steps to check hydrocarbons industry related corruption, internal conflicts and other paradox which hydrocarbons could bring about. In conclusion, the paper recommends that the Cyprus economy should remain diversified in order to avoid the negative experience of Nigeria.
\end{abstract}


Keywords: Cyprus hydrocarbons, Nigerian oil economy, resource curse, rescission, diversified economy

\section{Introduction}

Hydrocarbons/oil is still the greatest source of energy in the world, although its importance is diminishing with the development of alternative/environment-friendly sources of energy such as wind-power and solar energy. Importantly, most modern machineries, facilities and vehicles upon which development and human comfort heavily depend are powered by hydrocarbons or other by-products of petroleum. This underscores the domineering importance of hydrocarbons/oil in the world. For hydrocarbons/oil producing countries in particular, hydrocarbons/oil revenue is undoubtedly a veritable source of revenue to the national economy. On the contrary, hydrocarbons/oil can also become a curse or a paradox - for example, resulting in poverty, human rights abuses and conflicts. In fact, the struggle for the control of oil has caused internal conflicts, civil wars, international and proxy wars in some parts of the world. A good case in point is the US invasion of Iraq in 2003 which is widely regarded as a war to control the vast oil resources of the country (Bassil, 2012; Amin 2014).

It is well-known that Nigeria is Africa's leading oil-producing and exporting country, and a key member of the Organization of Petroleum and Exporting Countries (OPEC) (Ebeku, 2006). ${ }^{1}$ It is also common knowledge that in 2011 hydrocarbons reserve - specifically natural gas - was discovered in commercial quantities in Cyprus, within her Exclusive Economic Zone (EEZ) (Lakes, 2012: 81). Surely, the announcement of that discovery by Noble Energy International Ltd (Noble Energy) of the USA was good news for Cyprus (Haynes, 2015). Indeed, it was a major development in the country, especially as it promises a new of source of mega income to the economy.

\footnotetext{
${ }^{1}$ The Nigerian experience in oil exploitation shares a lot in common with other oil producing countries in the world, particularly oil producing less developed countries. However, for the purposes of this article it is sufficient to consider the Nigerian experience alone.

*This paper was originally presented at a one-day Conference held in the University of Nicosia UNESCO Amphitheatre, Nicosia, Cyprus on Monday, December 5, 2016 on the theme Energy Developments and Lessons for Cyprus, organized by the Department of Law, University of Nicosia, Cyprus. I am grateful to Prof. Achilles Emilianides, Head of the School of Law, University of Nicosia, Cyprus and Dr Emilios Solomou, Vice-President (Administration), University of Nicosia, Cyprus, for inviting me to the conference and for facilitating my trip. I am also grateful to Prof. Okey Onuchukwu, an economist with the University of Port Harcourt, for the insights he provided to me on Nigeria's oil economy during our discussions in the course of writing the conference paper and for availing me some useful statistics.
} 
It is a notorious fact that the Nigerian economy runs on oil. However, there is no gain-saying that it is a sweet-sour experience. Hence, it is important to interrogate the Nigerian oil economy and explore the lessons for the Republic of Cyprus, as she looks forward to earning hydrocarbons revenue from about 2022. This is the central objective of this article.

The article is divided into several sections for ease of presentation. It commences in section I with examination of the nature of the Nigerian economy before the discovery and exploitation of oil. This is followed in section II by an elaboration of the place of oil in the Nigerian economy from 1970 to 2017. Importantly, this section will make clear the huge contributions of oil to the Nigerian economy since 1970s. In section III, the article will analyse the problems associated with oil wealth in Nigeria and explain what lessons the Republic of Cyprus may derive from that. The last section of the article, section IV, will summarize the lessons for Cyprus and make appropriate recommendation(s).

\section{Nigerian economy before the discovery and exploitation of oil: a nutshell}

Nigeria was a British creation through a piecemeal process that culminated in the amalgamation of the southern and northern part of the present-day country in 1914 (Hatch, 1971; Ebeku 2006: 14-18). Before formal colonisation, Britain and other European powers were attracted to the area now constituting Nigeria by the prospect of trade (Niven, 1952: 136-142). In the words of a leading Nigerian historian, 'commerce was the fundamental relationship that bound Africa to Europe' (Dike, 1956: 1). In the main, the peoples of the area now called Nigeria traded their agricultural products with visiting European traders. As one author puts it, 'during the colonial period... Nigeria was exploited for its agricultural products' (Robinson, 1996: 9).

The British colonial rule in Nigeria lasted from about 1861 to 1960 when Nigeria was granted independence by the colonizers, after years of agitation by Nigerian nationalists. At independence in 1960 and up till the early 1970s the Nigerian economy was agrarian or 'agro-based'. The major agricultural products were Cocoa (produced in the West), groundnut and cotton (produced in the North), and palm oil (produced in the East). To be sure, although oil was discovered in Nigeria in 1956 and oil exports reached 5,100 barrels in 1958 , oil revenue did not play a major role in the Nigerian economy until the early 1970s. From statistical records, 'in the early 1960s, revenue from oil accounted for less than 10 per cent of Nigeria's revenue base' (Robinson, 1996: 9). More specifically, in 1963 and 1964 oil revenue was only 4.1 per cent and 5.9 per cent, respectively of the total revenue of the country (Graf, 1988: 218; Robinson, 1996: 8). 
To sum up, before the oil boom of the 1970s the bulk of Nigeria's revenue was from agriculture (Iwaloye and Ibeanu, 1997: 62-63). Notably, the Nigerian economy at that time was strong and healthy and its currency exchanged favourably as against the British Pounds Sterling and the US Dollars. Moreover, many citizens were gainfully employed in agriculture and the level of official corruption was low compared to the situation under the contemporary oil-economy.

\section{The place of oil in the nigerian economy: 1970s to 2017}

International oil prices escalated in the early 1970s, resulting in what was popularly known in oil producing and exporting countries as 'oil boom'. That development immediately led to a significant increase in the contribution of oil revenue to the Nigerian economy (Odularu, 2008). The following statistical records demonstrate this point:

Table A: Contribution of oil to Nigerian Federal Government Revenue, 1970 - 1979

\begin{tabular}{|c|c|}
\hline Year & Oil Revenue as \% of Total Revenue \\
\hline 1970 & $25.9 \%$ \\
\hline 1971 & $52.5 \%$ \\
\hline 1972 & $41.5 \%$ \\
\hline 1973 & $67.3 \%$ \\
\hline 1974 & $80.8 \%$ \\
\hline 1976 & $78.7 \%$ \\
\hline 1977 & $78.5 \%$ \\
\hline 1978 & $70.6 \%$ \\
\hline 1979 & $63.1 \%$ \\
\hline
\end{tabular}

Source: Graf (1988: 219); Ebeku (2006: 73). Central Bank of Nigeria Annual Reports, 197379

Table B: Contribution of Oil Revenue to Foreign Exchange Earnings

\begin{tabular}{|c|c|}
\hline Year & Oil Revenue as \% of Foreign Exchange \\
\hline $1960 \mathrm{~s}$ & $2.5 \%$ \\
\hline 1970 & 58.1 \\
\hline 1975 & 93.6 \\
\hline $1980 \mathrm{~s}$ & $98 \%+$ \\
\hline
\end{tabular}

Source: Graf (1988: 219); Ebeku (2006: 73); Central Bank of Nigeria Annual Reports, 197383

As can be seen from Table A, the contribution of oil revenue to the Federal Government revenue maintained a steady high from 1971 to 1979. Similarly, Table B shows that the contribution of oil revenue as a percentage of Nigeria's foreign exchange earnings 'escalated from 2.5 per cent of all such earnings in [1960s] to 93.6 per cent in 1975, and to 98 per cent and more through the first half of the 1980s' (Graf, 1988: 219). 
More recent statistics showing the place of oil revenue in Nigeria's economy can be found below in Table C, extracted from the Central Bank of Nigeria Statistical Bulletin 2015:

Table C: Contribution of oil to Nigerian Federal Government Revenue, 1980 - 2015

\begin{tabular}{|c|c|c|c|c|c|c|c|c|c|}
\hline Year & $\begin{array}{c}\text { Total } \\
\text { Revenue }\end{array}$ & $\begin{array}{c}\text { Oil } \\
\text { Revenue }\end{array}$ & $\begin{array}{l}\text { Non-Oil } \\
\text { Revenue }\end{array}$ & $\begin{array}{l}\text { Real } \\
\text { GDP } \\
\end{array}$ & $\begin{array}{c}\text { Oil } \\
\text { Revenu } \\
\text { e as } \\
\text { \%age } \\
\text { of } \\
\text { Total } \\
\text { Revenu } \\
\text { e } \\
\end{array}$ & $\begin{array}{c}\text { Non- } \\
\text { Oil } \\
\text { Revenu } \\
\text { e as } \\
\text { \%age } \\
\text { of } \\
\text { Total } \\
\text { Revenu } \\
\text { e } \\
\end{array}$ & $\begin{array}{c}\text { Total } \\
\text { Revenu } \\
\text { e as } \\
\text { \%age } \\
\text { of Real } \\
\text { GDP } \\
\end{array}$ & $\begin{array}{c}\text { Oil } \\
\text { Revenu } \\
\text { e as } \\
\% \text { age } \\
\text { of Real } \\
\text { GDP } \\
\end{array}$ & $\begin{array}{c}\text { Non- } \\
\text { Oil } \\
\text { Reve } \\
\text { nue } \\
\text { as } \\
\% \text { ag } \\
\text { e of } \\
\text { Real } \\
\text { GDP }\end{array}$ \\
\hline 1980 & 15.23 & 12.35 & 2.88 & 6501.83 & 81.09 & 18.91 & 0.23 & 0.19 & 0.04 \\
\hline 1981 & 13.29 & 8.56 & 4.73 & 15258.00 & 64.41 & 35.59 & 0.09 & 0.06 & 0.03 \\
\hline 1982 & 11.43 & 7.81 & 3.62 & 14985.08 & 68.33 & 31.67 & 0.08 & 0.05 & 0.02 \\
\hline 1983 & 10.51 & 7.25 & 3.26 & 13849.73 & 68.98 & 31.02 & 0.08 & 0.05 & 0.02 \\
\hline 1984 & 11.25 & 8.27 & 2.98 & 13779.26 & 73.51 & 26.49 & 0.08 & 0.06 & 0.02 \\
\hline 1985 & 15.05 & 10.92 & 4.13 & 14953.91 & 72.56 & 27.44 & 0.10 & 0.07 & 0.03 \\
\hline 1986 & 12.60 & 8.11 & 4.49 & 15237.99 & 64.37 & 35.63 & 0.08 & 0.05 & 0.03 \\
\hline 1987 & 25.38 & 19.03 & 6.35 & 15263.93 & 74.98 & 25.02 & 0.17 & 0.12 & 0.04 \\
\hline 1988 & 27.60 & 19.83 & 7.77 & 16215.37 & 71.85 & 28.15 & 0.17 & 0.12 & 0.05 \\
\hline 1989 & 53.87 & 39.13 & 14.74 & 17294.68 & 72.64 & 27.36 & 0.31 & 0.23 & 0.09 \\
\hline 1990 & 98.10 & 71.89 & 26.22 & 19305.63 & 73.28 & 26.73 & 0.51 & 0.37 & 0.14 \\
\hline 1991 & 100.99 & 82.67 & 18.33 & 19199.06 & 81.86 & 18.15 & 0.53 & 0.43 & 0.10 \\
\hline 1992 & 190.45 & 164.08 & 26.38 & 19620.19 & 86.15 & 13.85 & 0.97 & 0.84 & 0.13 \\
\hline 1993 & 192.77 & 162.10 & 30.67 & 19927.99 & 84.09 & 15.91 & 0.97 & 0.81 & 0.15 \\
\hline 1994 & 201.91 & 160.19 & 41.72 & 19979.12 & 79.34 & 20.66 & 1.01 & 0.80 & 0.21 \\
\hline 1995 & 459.99 & 324.55 & 135.44 & 20353.20 & 70.56 & 29.44 & 2.26 & 1.59 & 0.67 \\
\hline 1996 & 523.60 & 408.78 & 114.81 & 21177.92 & 78.07 & 21.93 & 2.47 & 1.93 & 0.54 \\
\hline 1997 & 582.81 & 416.81 & 166.00 & 21789.10 & 71.52 & 28.48 & 2.67 & 1.91 & 0.76 \\
\hline 1998 & 463.61 & 324.31 & 139.30 & 22332.87 & 69.95 & 30.05 & 2.08 & 1.45 & 0.62 \\
\hline 1999 & 949.19 & 724.42 & 224.77 & 22449.41 & 76.32 & 23.68 & 4.23 & 3.23 & 1.00 \\
\hline 2000 & 1906.16 & 1591.68 & 314.48 & 23688.28 & 83.50 & 16.50 & 8.05 & 6.72 & 1.33 \\
\hline 2001 & 2231.60 & 1707.56 & 903.46 & 25267.54 & 76.52 & 40.48 & 8.83 & 6.76 & 3.58 \\
\hline 2002 & 1731.84 & 1230.85 & 500.99 & 28957.71 & 71.07 & 28.93 & 5.98 & 4.25 & 1.73 \\
\hline 2003 & 2575.10 & 2074.28 & 500.82 & 31709.45 & 80.55 & 19.45 & 8.12 & 6.54 & 1.58 \\
\hline 2004 & 3920.50 & 3354.80 & 565.70 & 35020.55 & 85.57 & 14.43 & 11.19 & 9.58 & 1.62 \\
\hline 2005 & 5547.50 & 4762.40 & 785.10 & 37474.95 & 85.85 & 14.15 & 14.80 & 12.71 & 2.09 \\
\hline 2006 & 5965.10 & 5287.57 & 677.54 & 39995.50 & 88.64 & 11.36 & 14.91 & 13.22 & 1.69 \\
\hline 2007 & 5727.50 & 4462.91 & 1264.60 & 42922.41 & 77.92 & 22.08 & 13.34 & 10.40 & 2.95 \\
\hline 2008 & 7866.59 & 6530.60 & 1336.00 & 46012.52 & 83.02 & 16.98 & 17.10 & 14.19 & 2.90 \\
\hline 2009 & 4844.59 & 3191.94 & 1652.65 & 49856.10 & 65.89 & 34.11 & 9.72 & 6.40 & 3.31 \\
\hline 2010 & 7303.67 & 5396.09 & 1907.58 & 54612.26 & 73.88 & 26.12 & 13.37 & 9.88 & 3.49 \\
\hline 2011 & 11116.90 & 8878.97 & 2237.88 & 57511.04 & 79.87 & 20.13 & 19.33 & 15.44 & 3.89 \\
\hline 2012 & 10654.75 & 8025.97 & 2628.78 & 59929.89 & 75.33 & 24.67 & 17.78 & 13.39 & 4.39 \\
\hline 2013 & 9759.79 & 6809.23 & 2950.56 & 63218.72 & 69.77 & 30.23 & 15.44 & 10.77 & 4.67 \\
\hline 2014 & 10068.85 & 6793.82 & 3275.03 & 67152.79 & 67.47 & 32.53 & 14.99 & 10.12 & 4.88 \\
\hline 2015 & 6912.50 & 3830.10 & 3082.41 & 69023.93 & 55.41 & 44.59 & 10.01 & 5.55 & 4.47 \\
\hline
\end{tabular}

Source: Central Bank of Nigeria Statistical Bulletin, 2015

From Table $\mathrm{C}$ above, the position of oil as the dominant source of revenue in Nigeria from 1980 to as recently as 2015 cannot be in doubt. As could be observed, this is consistent with the position earlier noted in the 1970s. In its 1981 Annual Report, the Central Bank of Nigeria summed up the significant contribution of oil to the Nigerian economy as follows: 'Oil which 
was first discovered in 1956 and first exported in 1958 accounted for more than $90 \%$ of Nigerian exports by value and about $80 \%$ of government revenue as at December 31, 1981... [T] he overall contribution of the oil sector to the national economy also grew from an insignificant $0.1 \%$ in 1959 to $87 \%$ in 1976.' The 2003 budget speech of President Obasanjo further underscores this point: 'Oil will continue to be the major source of government revenue in the near term'. Even researchers have found that oil is the backbone of Nigeria's economy, as the following statement illustrates:

The Nigerian government... earned Naira 209.2 billion (Euro 1.3 billion) in excess [oil] revenue between January and May 2004... Nigeria's Central Bank further announced that the country's economy had grown at a record rate of 10.2 per cent in 2003 . Growth is mostly driven by the oil sector and record oil prices are producing more excess revenues... The Bank Governor was also optimistic about further strong growth in 2004 (emphasis added) (Afrol News, 2004).

\section{Problems of nigeria's oil-based economy and lessons for cyprus}

There is no doubt that for over 50 years Nigerian oil revenue (derived mainly from sale of crude oil, royalties and taxation of oil companies) has helped to fund rapid infrastructural developments in many Nigerian cities. For example, Lagos (Nigeria's former federal capital city) as well as the present federal capital city, Abuja, was constructed with 'petrodollars'. In fact, all major infrastructure/institutions - e.g. roads, bridges, schools, and universities - have been financed by oil revenue. Moreover, in 2014 oil revenue helped Nigeria to leap to the position of largest economy in Africa, overtaking South Africa. All this and more may be regarded as the benefits of Nigeria's oil wealth.

Never-the-less, there are still a lot of problems associated with the discovery and exploitation of oil in Nigeria. In other words, oil has not brought only blessings to Nigeria; it has also occasioned woes. In fact, Nigeria's overdependence on oil revenue is ill-advised, having regards to the problems associated with oil wealth as explicated below.

As at the time of writing in 2017, Cyprus economy was strong and healthy, based mainly on tourism, services and agriculture. As could be noted, this is similar to the position in Nigeria before the oil boom of the 1970s. As Cyprus looks forward to hydrocarbons/oil revenue from around 2022, it is important to explore the experience of Nigeria and extract some lessons that could help to maintain the country as a viable and heathy economy. For present purposes, it is sufficient to analyse some of the problems associated with oil wealth in Nigeria which hold some lessons for Cyprus - namely, oil 
curse, the 'Dutch disease', instability of international oil prices, conflicts, corruption, etc. These will be discussed in turn.

\section{(a) OIL CURSE}

In spite of the wealth and infrastructural developments that oil revenues have brought to Nigeria, it is a contradiction to note that the people of the country are still among the poorest peoples in the world. As one observer puts it, "in spite of oil revenues estimated at some $\$ 350$ billion over three decades, it seems that the average Nigerian was actually worse off in relative terms' (Belinksi, 2015). In fact, statistical records show that over $60 \%$ of Nigerians live on less than USD2 per day (Essia, 2012).

This situation is even more acute in the Niger Delta region of Nigeria from where the country derives enormous oil revenues (Essia, 2012). In a recent article, Osaghae (2015) explored the developmental outcome of resource abundance "when the analytical focus shifts from the macro (national) to the micro (subnational) level, especially to areas where resource abundance is expected to have its greatest impact'. He found that in the Niger Delta region the resource curse includes 'environmental devastation, relative deprivation, resource distribution injustices, political marginalization and material underdevelopment'. He blames the subnational governments especially for this situation (See also Baghebo and Atima, 2013: 104-5). But, in my judgment, the major blame should rest on the national government which owns all the natural resources in the country, including oil, by virtue of constitutional and statutory provisions (Ebeku, 2006).

More importantly, the widespread poverty in oil-rich Nigeria is a classic example of 'oil curse'. The theory of 'oil curse' (also known as 'resource curse' or the 'paradox of plenty') essentially states that countries with abundant natural resources, such as oil or other minerals, tend to have less economic growth, more conflict or war, and high-level of individual poverty compared to countries with fewer natural resources (Wenar, 2016: xv; Ross, 2004; Ross, 2004a; Hausmann and Rigobon, 2002). As Basedau and Lay (2009) have noted:

The growing literature on the 'resource curse' (Sachs \& Warner, 1995; Auty, 2001) and the 'paradox of plenty' (Karl, 1997) has been linking the extraction of natural resources to corruption, authoritarianism, economic decline and civil war. In the study of peace and war, natural resources are said to provide both finance and motive for armed conflict and to create indirect economic and institutional causes of violence (Ross, 2006; Humphreys, 2005; Fearon, 2005). Numerous empirical studies have provided evidence that natural-resource dependent and rich countries indeed seem to be more likely to lapse into violence... 
In a recently published book entitled Blood Oil: Tyrants, Violence and the Rules That Run the World, Leif Wenar (2016: xv) reported his findings thus:

For forty years, oil states have been noisy distractions to the quiet successes of the developing world. While non-oil states have generally been getting richer, freer, and more peaceful, the oil states are no richer, no more free, and no more peaceful than they were in 1980. Many oil states have even gotten worse - Gabon's average income fell by almost half over the quarter century from 1980; Iraq's fell by a full 85 percent. Long internal conflicts have ravaged countries like Algeria, Angola, Columbia, and Nigeria...These figures show what political scientists call the 'resource curse',

Although the theory of 'resource curse' has been doubted and criticized by some authors (e.g. Basedau and Lay, 2009), there are undisputable examples of oil-rich countries, such as Nigeria and the Sudan, where the citizens are among the poorest people in the world (Ebeku, 2006: 282-291; Rolandsen, 2012). The reason for this includes corruption, concentration of funds in the hands of a few, mismanagement of oil revenues by successive governments and lack of good governance. For Cyprus, the lesson to learn here is that while hydrocarbons could provide mega revenues for the economy, it may also be a curse as the experience of Nigeria and many other resource-rich countries has shown. To avoid this, Cyprus must take institutional and other measures to check the factors that brought about 'oil curse' in Nigeria and elsewhere, as mentioned above. Some resource-rich countries, such as the US and the UK, have eventually managed to avoid the paradox of plenty.

\section{(b) THE DUTCH DISEASE SYNDROME}

It is well-known that since the 1970s when Nigeria began earning increasing income from the export of crude oil, other sectors of the economy - particularly agriculture and manufacturing - have been neglected (Ebeku, 2006: 72). This situation illustrates what economists call the 'Dutch disease' syndrome. In development economics literature, 'Dutch disease' essentially means the impediments of oil revenue to economic growth and development of oil-dependent states (Otawa, 2001:111). As Otaha (2012: 83-84) explains:

The enormous influx of cash resulting from oil tends to foster wasteful, overzealous and imprudent expenditure. High oil revenue raises exchange rates, promote [sic] adverse balance of payment as the cost of imports rises. In short, it kills incentive to risk investment in non-oil sectors, the competitiveness of all nonoil sectors such as agriculture and manufacturing industries have 
been crowded out. The employment of both labour and other resources has been exchanged for unemployment as the government and private expenditure multipliers have been exported abroad. Together, these forces constitute what Michael Ross (2001:114) calls the rentier effect, oil states being rentier states.

Belinksi (2015) has admirably described the debilitating effect of 'Dutch disease' on an economy and the people affected, and suggested that the disease is better prevented than cured. Using Nigeria as a case-study, he explained how 'Dutch disease' and falling international oil prices combined to lead Nigeria into recession in 2016. In summary, he stated the painful effects of 'Dutch disease' in the following words:

Time again, studies have confirmed that resource-poor countries outperform commodity exporters in terms of economic growth by a considerable margin. What's more, developing countries stricken with the Dutch disease tend to perform worse than their non-exporting counterparts in rule of law, income distribution and overall good governance. Populations concentrated around resource-rich areas develop rent-seeking behavior ... Oxford University Professor Paul Collier even argues that oil rich countries have higher chances of being engulfed in wars than their resource poor counterparts.

With specific regard to the experience of Nigeria, he blames wrong policy choices of successive governments for the country's economic woes. In his words: 'Nigeria, which clocks in at 2 million barrels a day and is Africa's largest exporter, clearly displays the damaging effects policy myopia can have on a resource rich country' (Belinksi, 2015). He was right. Nigeria abandoned agriculture and other sources of revenue pre-oil wealth revenue. This resulted in a mono-product economy with all the associated risks. Besides, Nigeria also exemplifies lawlessness, bad governance, and inequity in income distribution (Ebeku, 2006).

Having analysed the Nigerian case of 'Dutch disease', Belinksi (2015) concluded that 'the case for Nigeria to move away from its reliance on oil is quite compelling, as the country is almost a textbook case of the Dutch disease...' According to him, '[over] dependence on natural resources makes the economy vulnerable to commodity prices' (Belinksi, 2015). Undoubtedly, Nigeria over depends on oil revenue and lacks product diversity. In other words, the Nigerian economy relies only on the export of a primary commodity - namely, oil. This situation predisposes it to recession when international oil prices fall. Interestingly, this was also the experience of the US in Post-Second World War. As Mathew has rightly noted, a sharp decline 
in oil prices 'have been identified as a major cause in seven out of eight post WW II recessions in the US' (Mathew, undated).

Obviously, there is a lesson here that Cyprus should learn from the outset in order to avoid the experience of Nigeria - viz: avoid over-dependence on income from any natural resource in the country; maintain a diversified economy. Presently, Nigeria seems to have understood the need to move away from over-dependence on oil revenue as she is striving to revive and promote the agricultural sector. In fact, from about September 2017 some Nigerian agricultural products are being exported to other African countries, Europe and America. By this development, Nigeria is beginning to return to its original sources of wealth.

\section{(c) INSTABILITY OR UNCERATINTY OF INTERNATIONAL OIL PRICES}

There is no gain-saying that international oil prices are notoriously unstable or uncertain. The instability/uncertainty of international oil prices is another important reason why resource-rich countries should ensure that they maintain real diversified economy and avoid over-dependence on natural resource revenues. The experience of Nigeria and other oil-rich countries which overly depend on oil revenues has shown that over-dependence on revenues from natural resources is not only foolish but also a recipe for economic troubles in times of low international oil prices, as happens from time to time. A recent example can be found in Nigeria. With decreasing international oil prices since 2014, the Nigerian oil economy was hard hit and slipped into recession in 2016. In other words, low international oil prices caused external shock on the economy.

Related to the foregoing, another cause of the recent recession was the failure of Nigeria's oil wealth to add value to the economy as a result of certain practices and policies (Baghebo and Atima, 2013: 105). For example, crude oil is exported and refined products are imported for domestic needs. The problem in this situation lies in the fact that much of the 'petrodollars' earned by Nigeria is virtually 'recycled' to importing countries when she imports refined oil products and other commodities from crude oil importing countries. Mathew makes this point well when he said:

... [O]il revenues earned by producers are to a large extent

"'recycled' 'back to consumers in imports of all types of goods and services. In this way, oil-importing nations earn back much of the petrodollars they originally spend on oil purchases... (Mathew, undated).

Now, the lesson for Cyprus here is that international oil/hydrocarbons prices are unstable or uncertain and a fall in prices could introduce external 
shock on the economy. To check this likelihood Cyprus must ensure that its economy remains diversified even with the coming of oil revenues.

\section{CONFLICT, OIL PRODUCTION AND THE ECONOMY}

There is hardly any country in the world without one form of conflict or the other. However, this is more so in the case of resource-rich countries. In fact, it has been found that oil-rich countries are prone to conflicts (Collier, 2010). Nigeria and the Sudan illustrate this point (Belinksi, 2015; Rolandsen, 2012). Between 1967 and 1970 Nigeria was embroiled in a civil war, widely regarded as a struggle for the control of the oil endowments in the then Eastern Region of the country. In the case of the Sudans (Sudan and Southern Sudan), it was also the case that distribution of oil revenue caused and fuelled the civil war in the country and led to the eventual breakup of the country. The point to make here is that during wars or conflicts oil production activities are slowed and oil facilities may be attacked. The natural result of such eventuality is a cut in oil production and the consequent effect of drop in oil revenues. This was the experience of Nigeria and the Sudan during their civil wars and during heightened conflicts.

Over the past 50 years of oil production, particularly since the 1990s, Nigeria experiences low oil production from time to time as a result of conflict situations in the oil-producing region. From time to time, militant youths in the Niger Delta region agitating for greater participation in oil exploitation and equitable sharing of oil revenue disrupt oil production by damaging oil production pipelines and/or blowing-up oil facilities. This situation often introduce internal shock on the economy, which could lead to rescission, particularly if this combines with external shock due to low international oil prices.

The likelihood of disruption of hydrocarbons production facilities by militants should be a serious concern for Cyprus because of the long-standing hostilities between the Greek and Turkish Cypriots. Since 1974, the country has been divided between the Greek Cypriots in the south and the Turkish Cypriots in the north - a situation created, encouraged and sustained by the Republic of Turkey on the ground of protecting the Turkish Cypriots.

Already, Turkey and Turkish Cypriots (occupying the unrecognized Turkish Republic of Northern Cyprus in the north of Cyprus) have threatened to disrupt hydrocarbons/oil exploration in the Exclusive Economic Zone (EEZ) of Cyprus (Energy Boardroom 2015: 21). The fact that they have not carried out the threat does not indicate that they would not seek to disrupt hydrocarbons/oil production in the future. Although the President of Cyprus has declared that hydrocarbons/oil revenues would be shared by both the Greek and the Turkish Cypriots, there remains a possibility that the question of equitable distribution or fair sharing formula may well arise in the future - 
especially if the separation between the two communities endures. In that case, the country could face militant attacks on hydrocarbon facilities and cut in resource production as often happens in Nigeria.

In fact, the basis for disagreement already exists. Some Greek Cypriots disagree with the position of the President of the Republic on sharing hydrocarbons revenue and this may become a political/electoral issue as long as the 'Cyprus problem' - an expression used to describe the separation of the Greek and Turkish Cypriots and the occupation of Northern Cyprus by the Turkish military since 1974 - remains unresolved.

\section{(e) CORRUPTION}

One of the critical problems that beset oil-producing and exporting countries, especially in less developed countries, is mammoth corruption by state officials and the personnel of state oil-related institutions. In Nigeria, one of such oil-related institutions is the Nigerian National Petroleum Corporation (NNPC). Similar institution exists in Cyprus and is called Cyprus Hydrocarbons Company (CHC). The sad reality is that much of Nigeria's oil revenue disappears into the private pockets/offshore accounts of corrupt officials of the oil-related institutions and some privileged government officers in charge of such institutions as well as some privileged elites (Baghebo and Atima, 2013: 112). In fact, corrupt practices bring about a situation where Nigeria does not know the accurate volume of daily oil production, notwithstanding the existence of the Nigerian Extractive Industries Transparency Initiative (NEITI) whose vision is to have a country 'whose extractive sector is transparent, accountable, and beneficial to all Nigerians'.

In the 1990s, successive military governments stashed away millions of 'petrodollars' in private accounts in Europe, America and other parts of the world. This is a notorious fact. Also well-known is that some Nigerian officials have been convicted and some are wanted or are standing trials in various countries on charges related to corruption and money laundering. ${ }^{3}$ One of the most recent examples is Nigeria's former petroleum Minister Mrs. Diezani Alison-Madueke whose trial on charges of corruption in a British court in London was still pending as at, November 2017. The notoriety and extent of corruption in Nigeria probably led Nigeria's President Buhari to admit to the suggestion of British Prime Minister David Cameron that Nigeria is 'fantastically corrupt'.

\footnotetext{
${ }^{2}$ The Mission of NEITI is 'to institutionalise accountability mechanisms and processes aimed at instilling a culture of transparency in Nigeria's extractive sector for the benefit of all'.

${ }^{3}$ Some of the countries listed as holding such corrupt money include Switzerland, the United Kingdom, the US, St. Vincent, Malta, and Cyprus.
} 
In light of the forgoing Nigerian experience, Cyprus must brace up to the fact that hydrocarbons revenue may breed corruption in the country and must begin now to plan how to checkmate the evil. Nigeria has two anti-corruption agencies, namely, the Economic and Financial Crimes Commission (EFCC), and the Independent Corrupt Practices Commission (ICPC), which are designed to checkmate corruption in the country. However, both of them are ineffective due mainly to the fact that they are virtually controlled by the Office of the President and are largely used to chastise political opponents. Leaning from the Nigerian experience, Cyprus must allow any established anti-corruption agency to be truly independent and effective and not an appendage to any office of government. Importantly, this will not only help to curb the incidence of corruption, but will also help to control inflation and stabilise the economy for the general good of the people.

ENVIRONMNETAL PROBLEMS

It is platitudinous to say that exploitation of natural resources naturally involves environmental pollution. This is why measures to ensure sustainable development are important. In general, the environment is our natural abode, and consists of air, water and land. Although there are so many definitions of environmental pollution/pollution, for present purposes it is sufficient to rely on the definition of the Council of the European Union in the Directive Concerning Integrated Pollution Prevention and Control 1996, where 'pollution' is defined as follows:

The direct or indirect introduction as a result of human activity, of substances, vibrations, heat or noise into the air, water or land which may be harmful to health or the quality of the environment, result in damage to material, property, or impair or interfere with amenities and other legitimate uses of the environment (E.C. Council Directive 96/61, 24 September 1996).

The environment provides the resource base for extraction of natural resources and the process of exploration, exploitation, production and transportation can have far-reaching impacts on the environment (Puvimanasinghe, 2000: 38). In other words, as O'Faaircheallaigh (1991: 251) has rightly pointed out, 'modern mining projects have the potential to create enormous environmental damage'. Young (1995: 157) categorically makes the point that 'environmentally, modern mining operations have been destructive. The removal of a non-renewable resource [such as oil or hydrocarbons] usually causes some environmental damage'. Hence, Josephs (1967) was right to conclude that 'the threats of pollution are real. Their economic [environmental, social and cultural] consequences are real. Their health consequences are real. There are sufficient data to make strong cases based on facts' (Quoted in Ebeku, 2006: 135). 
In Nigeria, environmental pollution is a blight on the Nigerian oil industry. Frequent oil spillages and intensive gas flaring have devastated the environment in great measure and caused incalculable environmental, socioeconomic and cultural damage (Ebeku, 2006: Chapter 4). Despite denials by oil multinationals operating in the country, there is no doubt that the Nigerian environment - specifically, the Niger Delta area where oil operations are taking place - has been devastated in the course of over 50 years of oil exploration and exploitation in Nigeria. The report of the United Nations Environment Programme (UNEP) on Ogoni-land published on August 4, 2011, eloquently attests to this (UNEP, 2011). Sadly, this is the case in spite of the fact that Nigeria has a satisfactory body of laws on environmental protection. The truth is that, because of the importance of oil to the Nigerian economy successive governments and relevant government agencies do not enforce the extant laws even where oil operations manifestly violate relevant environment protection laws.

In accordance with international industry best practices and in compliance to Cypriot law and EU regulations, Noble Energy has already conducted 'Environmental Impact Assessment for Exploratory Drilling of Block 12, Offshore Cyprus', and this was published in September 2011. Despite the shortcomings and questionable conclusions of the report, it is important to note the acknowledgment of potential environmental damage in the course of hydrocarbons operations:

The probability of a significant hydrocarbon release during the project is very small, especially since gas is the target hydrocarbon. An accidental release of diesel fuel, e.g. from the rupture of the fuel tank on the drilling vessel or a release during the fuelling operations offshore, is more likely than a crude hydrocarbon release ... If a large diesel release did occur, it could affect marine life, such as plankton, fishes, marine mammals, sea turtles and birds, and possibly affect socioeconomic resources. If the hydrocarbon reached the shoreline, it could affect coastal habitats, including beaches and seagrass beds, rocky shores and associated wildlife... (emphasis added).

This frank acknowledgment puts Cyprus on notice that hydrocarbons exploration and exploitation (more so where oil is the target hydrocarbon) could bring much money, but could also cause much environmental problems that may inevitably damage the economy. The UNEP Report on Ogoni reveals mammoth environmental damage with reverberating consequences on the people and the economy, and this was due partly to the refusal of Nigerian administrative and judicial authorities to enforce relevant oil-related environmental protection laws in deference to the importance of oil revenue to the Nigerian economy (UNEP, 2011). 
As is the case in Nigeria, Cyprus has a body of domestic laws (harmonised with relevant EU laws/regulations on environment) that could protect the Cypriot environment from hydrocarbon-related pollution. Even so, she should learn from the Nigerian experience that privileging hydrocarbons revenue over enforcement of extant laws and/or not making necessary environmental protection laws could spell doom on the Cyprus economy.

MANAGEMENT AND SHARING OF OIL REVENUE

The management and sharing of oi/hydrocarbons revenue is of crucial importance because any disagreement could be the source of conflict, which could hurt hydrocarbons/oil production and destabilise the economy. In Nigeria, the sharing of oil revenue has been a source of long-standing disputes and this has adverse effects on the economy. The central complaint of agitators for equity is that the management of oil revenue is firmly in the hands of the majority ethnic groups in the country who have no oil in their homeland, and that the people of the minority ethnic groups where the oil operations take place are not allowed to participate in the oil industry. Moreover, they complain that distribution of oil revenue is inequitable in the sense that while oil exploitation takes place in the homeland of minority ethnic groups in the Niger Delta region and the people suffer adverse environmental, socioeconomic and cultural costs, oil revenue is mainly used to develop the homeland of the majority ethnic groups and benefit their people (Ebeku, 2006: Chapter 6).

Over the years, it has not been possible to find an acceptable revenue sharing formula in Nigeria, particularly with regard to the sharing of oil revenue (Ebeku, 2006: 291-300). The proviso to section 162(2) of the 1999 Constitution of Nigeria entrenches 'the principle of derivation in any formula the National Assembly may come up with'. More importantly, 'by this principle "not less than thirteen per cent" of the revenue accruing to the Federation Account directly from any natural resource shall be payable to a State of the Federation from which such natural resources are derived' (Attorney of the Federation v. Attorney-General of Abia State \& 35 Ors. (No. 2) [2002] 6 NWLR (Pt. 764) 542). The proviso has been implemented since the year 2000. However, the Niger Delta people want it to be increased to at least $50 \%$ while some people of the other States outside the Niger Delta want it reduced to $10 \%$ or below.

In the Republic of Cyprus, populated by two main ethnic and antagonistic communities (Greek and Turkish Cypriots), which have been living in separation since 1974, the management and distribution of hydrocarbons/oil wealth may well be controversial as is the case in Nigeria. At the time of writing this article in 2017, there was ongoing debate in the country on the issue. In fact, this was one of the issues debated at a one-day 
conference held on November 26, 2011 in the Nicosia Buffer Zone on the theme 'Cyprus Offshore Hydrocarbons: Wealth Distribution and Regional Politics' (Faustmann, Gurel and Reichberg 2012: 6). ${ }^{4}$ An indication of the controversial nature of this issue can be found in the contribution of Leventis (2012: 10) at the conference:

... we equally witness an all too compromising stance of the Cyprus government: the Christofias administration, despite the internal opposition criticism that he comes up with premature offers to the Turkish side, has pledged that any prospective proceeds out of the natural resources exploitation are guaranteed to be used for the interests of both Cypriot communities - a promise, it should be noted, that comes on top of a raft of post2004 measures in favour of the Turkish Cypriot community.

This controversial position can also be found in an interview granted in 2011 by Michalis Sarris, former Finance Minister of the Republic of Cyprus and Member of the Working Group on Economic Matters in the Cyprus reunification talks. His words:

... I think we need to be honest about this. The Turkish Cypriot side ... has always insisted on separate institutions. The only time that they talk about doing something together is when they talk about the redistribution of taxes raised on the Greek side, and when we talk about the gas. So, one has to be consistent: do you want to be together, or do you want to be separate except when it comes to revenue transfer from one side to the other? (Hazou, 2012: 90).

Learning from the Nigerian experience, Cyprus needs to handle the issue of management and distribution of hydrocarbons revenue from the outset in a manner that will be fair to both communities. Importantly, both sides must not insist on fixed positions.

\section{Conclusion}

This article has amply demonstrated that the Nigerian oil-based economy is a mixed bag of blessings and curse. In fact, it may well be more of curse than blessings considering the problems associated with oil wealth as discussed in this article. Specifically, some problems associated with the exploitation of oil and over-dependence on oil revenue in Nigeria were identified and analysed and the lessons for Cyprus clearly pointed out.

More specifically, this article shows that Cyprus should learn from Nigeria, among others, that hydrocarbons/oil wealth may become a curse -

\footnotetext{
${ }^{4}$ The conference was jointly organised by Friedrich Ebert Foundation (FES) and the Peace Research Institute Oslo (PRIO) Cyprus Centre.
} 
resulting in poverty and human rights abuses, for example - except proper precautions are taken. A second lesson is that hydrocarbons/oil may lead the country to 'Dutch disease' if other sectors of the economy are abandoned as a result of 'oil-boom'. Thirdly, hydrocarbons/oil may breed corruption in Cyprus except conscious efforts are made to check this likelihood. Fourthly, hydrocarbons/oil may generate or exacerbate internal conflict which could cause low production and thereby introduce internal shock on the economy as a result of reduced revenue. Fifthly, there could also be external shock on the economy as a result of low international hydrocarbons/oil prices which prevails from time to time. Sixthly, the management and distribution of hydrocarbons/oil revenue may raise problems of fairness or equity which could ultimately affect the economy, except it is well managed. Lastly, hydrocarbons/oil exploitation may result in serious environmental damage unless appropriate environment protection laws are in place and are effectively enforced.

On the whole, the central message is that Cyprus should not be starryeyed about the discovery of hydrocarbons within its EEZ and the prospect of future discoveries, exploitation and hydrocarbons/oil mega revenue. Indisputably, the discovery of hydrocarbons in Cyprus is a welcome development but it did not and should not signal the end of hard work in the country. The existing Cyprus diversified economy - i.e. an economy whose revenue derives from different sources, including tourism, services and agriculture - is strong and healthy and should be maintained. Importantly, the country must not make the mistake of Nigeria and suffer 'Dutch disease' by abandoning other sources of revenue when hydrocarbons/oil revenue start entering the economy. A diversified economy is the only sure way to sustainable prosperity. In summary, the problems associated with the Nigerian oil wealth as discussed in this article clearly hold useful lessons for Cyprus, and eloquently make a case for a diversified and sustainable economy.

Another reason why Cyprus should ensure that its economy remains diversified lies in the fact that the importance of oil in the world is diminishing as alternative sources of energy are being developed and concern for the environment continues to increase and compel the use of alternative/renewable energy which cause less damage to the environment (Helm, 2016). In fact, it is now the case that electric-powered cars are increasingly being manufactured to replace petrol or diesel engine cars. As it is well-known, carbons produced by the burning of petroleum products, such as premium motor spirits (PMS) or diesel in vehicles, contribute greatly to global warming and climate change which are arguably the greatest environmental concerns of mankind in the present-day. More importantly, in view of the diminishing importance of non-renewable energy, the likelihood is that Cyprus hydrocarbons/oil revenue - expected from 2022 - may not be 
as great as the present case in Nigeria as well as in the other existing oil producing and exporting countries.

In the end, a fitting summary of the message conveyed by this article can be found in the following well-crafted and evergreen words of Kapucinski $(1982: 34-35):^{5}$

Oil [hydrocarbons] kindles extraordinary emotions and hopes, since oil is above all a great temptation. It is temptation of ease, wealth, fortune, power. [But] oil, though powerful, has its defects...Oil is a resource that anesthetizes thought, blurs vision, corrupts... Look at the Ministers from oil countries... [Above all] ...oil creates the illusion of a completely changed life, life without work, life for free.... The concept of oil expresses perfectly the eternal human dream of wealth achieved through lucky accident.... In this sense oil is a fairy tale and like every fairy tale a bit of a lie.

\section{References:}

1. Afrol News (2004, 26 May). Nigeria's economic growth reaches new records. Available at < http://www.afrol.com/articles/12782 > (Retrieved 25/4/17).

2. Amin, Z. T. K. (2014). Why did the United States lead an invasion of Iraq in 2003? International Journal of Political Science and Development, Vol 2, Issue 11, pp. 301-308.

3. Baghebo, M. and Atima, T. O. (2013). The impact of petroleum on economic growth in Nigeria. Global Business and Economics Research Journal, Vol 2, Issue 5, pp. 102-115.

4. Belinski, S. (2015). Will Falling Oil Prices Resolve Nigeria's Dutch Disease? Roubini's EconoMonitor, 23 January. Available at < http://archive.economonitor.com/blog/2015/01/will-falling-oil-pricesresolve-nigerias-dutch-disease/ > (Retrieved 20/4/17).

5. Basedau, M. and Lay, J. (2009). Resource Curse or Rentier Peace? The Ambiguous Effects of Oil Wealth and Oil Dependence on Violent Conflict. Journal of Peace Research, Vol 46, Issue 6, pp. 757-776.

6. Bassil, Y. (2012). The 2003 Iraq War: Operations, Causes, and Consequences. Journal of Humanities and Social Science, Vol 4, Issue 5, pp. 29-47.

7. Central Bank of Nigeria (1973-1983). Annual Reports. Nigeria: Federal Government Printer.

8. Central Bank of Nigeria (2015). Statistical Bulletin. Nigeria: Federal Government Printer.

${ }^{5}$ Quoted in Peluso, N. L. and Watts, M. (2001). 
9. Dike, K.O. (1956). Trade and Politics in the Niger Delta. Oxford.

10. Ebeku K.S.A. (2006). Oil and the Niger Delta People in International Law: Resource Rights, Environmental and Equity Issues. Koln, Germany.

11. EnergyBoardroom. (2015). Cyprus: Inside Oil \& Gas-Special Report. London.

12. Enyaribe, O. (2004). Battle of the Niger Delta. Alexander's Oil and Gas Connections, 22 December. Available at <http://www.gasandoil.com/goc/news/nta45100.htmm> (Retrieved 24/11/16).

13. Essia, U. (2012). Jobless Growth, the 'Active Poor' Phenomenon and Youth Unemployment in Cross River State, Nigeria: Leaning points from Europe 2020' Flagship Initiative's Agenda for new skills and jobs. Science Journal of Economics, Volume 2012, Article ID sje-108, 16 Pages, 2012.

14. Faustmann H., Gurel, A. and Reichberg, G.M. (eds.) (2012). Cyprus Offshore Hydrocarbons: Regional Politics and Wealth Distribution. Nicosia and Oslo.

15. Graf, W. (1988). The Nigerian State: Political Economy, State, Class and Political System in Post-Colonial Era. London.

16. Hatch, J. (1971). Nigeria: A History. London: Currey.

17. Hausmann, R. and Rigobon, R. (2002). An Alternative Interpretation of the 'Resource Curse': theory and policy implications. National Bureau of Economic Research/University of California.

18. Hazou, E. (2012). Offshore Hydrocarbons and Wealth Distribution in Cyprus: Interviews with Michael Sarris and Mustapha Besim. In H. Faustmann, A. Gurel and G.M. Reichberg (eds.), Cyprus Offshore Hydrocarbons: Regional Politics and Wealth Distribution, pp. 87-96. Nicosia and Oslo.

19. Haynes, L. (2015). Cyprus: Lifting the Lid on Offshore Natural Gas Bonanza. Oil \& Gas Financial Journal, 02/16/2015. Available at < http://www.ogfj.com/articles/print/volume-12/issue-

2/features/special-report-cyprus/cyprus-lifting-the-lid-on-an-offshorenatural-gas-bonanza.html_> (Retrieved 7 November, 2016).

20. Helm, D. (2016). The Future of Fossil Fuels - Is it the end? Oxford Review of Economic Policy, Vol 32, Issue 2, pp. 191-205.

21. Iwaloye, L.B. and Ibeanu, A. (1997). The Peoples of Nigeria. In F.U. Okafor (ed.), New Strategies for Curbing Ethnic and Religious Conflicts in Nigeria, pp. 41-68. Enugu.

22. Lakes, G. (2012). Cyprus Hydrocarbons: The Dilemmas of Early Development. In H. Faustmann, A. Gurel and G.M. Reichberg (eds.). 
Cyprus Offshore Hydrocarbons: Regional Politics and Wealth Distribution., pp. 81-96. Nicosia and Oslo.

23. Leventis, Y. (2012). Projecting for Control of Warm Waters: Turkey's Posturing for Hydrocarbon Hegemony in the Eastern Mediterranean. In H. Faustmann, A. Gurel and G.M. Reichberg (eds.), Cyprus Offshore Hydrocarbons: Regional Politics and Wealth Distribution, pp. 7-15. Nicosia and Oslo.

24. Lujala, P., Gleditsch, N.P. and Gilmore, E. (2005). A Diamond Curse? Civil War and a Lootable Resource. Journal of Conflict Resolution, Vol 49, Issue 4, pp. 538-562.

25. Luong, P. J. and Weinthal, E. (2006). Rethinking the Resource Curse: Ownership Structure, Institutional Capacity, and Domestic Constraints. Annual Review of Political Science, Vol 9, pp. 241-263.

26. Mahdavy, H. (1970). Patterns and Problems of Economic Development in Rentier States: The Case of Iran. In M. A. Cook (ed.), Studies in the Economic History of the Middle East, pp. 37-61. Oxford: Oxford University Press.

27. Mathew, R. (undated). Effect of Declining Oil Prices on Exporting Countries. Available at:

http://web.stanford.edu/class/e297c/trade_environment/energy/heffec t.htl> (Retrieved 30/5/2017).

28. Mehlum, H., Moene K., and Torvik, R. (2006). Institutions and the Resource Curse. Economic Journal, Vol 116, Issue 508, pp. 1-20.

29. Michael, L. R. (2012). The Oil Curse. Princeton: Princeton University Press.

30. Nivan, C.R. (1952). A Short History of Nigeria. London.

31. O'Faircheallaigh, C. (1991). Resource Exploitation and Indigenous People: Towards a General Analytical Framework. In P. Jull and Roberts S. (eds.), The Challenge of the Northern Regions, pp. 229-271. Darwin: Australian National University.

32. Obasi, N. O. (2016). The Oil Price Fall and the Impact on the Nigerian Economy: A Call for Diversification. Journal of Law, Policy and Globalization, Vol 48, pp. 94-93.

33. Odularu, G.O. (2008). Crude Oil and the Nigerian Economic Performance. Oil and Gas Business. Available at: < http://www.ogbus.ru/eng/ > (retrieved 17/11/17).

34. Ogochukwu, O.N. (2016). The Oil Price Fall and the Impact on the Nigerian Economy: A Call for Diversification. Journal of Law, Policy and Globalization, Vol 48, pp. 84-93.

35. Osaghae, E.E. (2015). Resource curse or resource blessing: the case of the Niger Delta 'oil republic' in Nigeria. (2015). Journal of 
Commonwealth and Comparative Politics, Vol 53, Issue 2, pp. 109129.

36. Otaha, J.I. (2012). Dutch Disease and Nigeria Oil Economy. Africa Research Review, Vol 6, Issue 1, pp. 82-90.

37. Otawa, M. (2001). The National Security Strategy of the United States. Washington DC: US Government Printing Office.

38. Oystein, H. R. (2012). Victims of the Resource Curse: The Case of the Two Sudans. In H. Faustmann, A. Gurel and G.M. Reichberg (eds.), Cyprus Offshore Hydrocarbons: Regional Politics and Wealth Distribution, pp. 73-80. Nicosia and Oslo.

39. Paul, C. (2010). The political economy of natural resources. Social Research, Vol 77, Issue 4, pp. 1105-1132.

40. Peluso, N. L. and Watts, M. (eds.) (2001). Violent Environments, p. 203. Ithaca and London: Cornell University Press.

41. Puvimanasinghe S.F. (2000). Development, Environment, and the Human Rights Dimension: Reflections on the Role of law and Policy in the Third World, with Particular Reference to South Asia. Sri Lanka Journal of International Law, Vol 12, pp. 35-54.

42. Robinson, D. (1996). Ogoni: The Struggle Continues. Geneva.

43. Rolandsen, O.H. (2012). Victims of the Resource Curse: The Case of the Two Sudans. In H. Faustmann, A. Gurel and G.M. Reichberg (eds.). Cyprus Offshore Hydrocarbons: Regional Politics and Wealth Distribution, pp. 73-80. Nicosia and Oslo.

44. Ross, M. L. (2001). Does Oil Hinder Democracy? World Politics, Vol 53, Issue 3, pp. 325-361.

45. Ross, M. L. (2003). The Natural Resource Curse: How Wealth Can Make You Poor. In I. Bannon and P. Collier (eds.). Natural Resources and Violent Conflict: Options and Actions, pp. 17-42. Washington, DC: World Bank.

46. Ross, M. L. (2004). What Do We Know About Natural Resources and Civil War? Journal of Peace Research, Vol 41, Issue 3, 337-356.

47. Ross, M.L. (2004a). How Do Natural Resources Influence Civil War? Evidence From Thirteen Cases. International Organization, Vol 58, Issue 1, pp. 35-67.

48. Ross, M. L. (2006). A Closer Look at Oil, Diamonds, and Civil War. Annual Review of Political Science, Vol 9, pp. 265-300.

49. Sachs, J. D. and A. M. Warner. (1995). Natural Resource Abundance and Economic Growth. Development Discussion Paper, 517a. Harvard Institute for International Development.

50. Scott, B. (2015). Will Falling Oil Prices Resolve Nigeria's Dutch Disease? EconoMonitor, 23 January, 2015; available at: < 
http://www.economonitor.com/blog/2015/01/will-falling-oil-pricesresolve-nigerias-dutch-disease/ > (Retrieved on 27/11/17).

51. Smith, B. (2004). Oil Wealth and Regime Survival in the Developing World, 1960- 1999. American Journal of Political Science, Vol 48, Issue 2, pp. 232-246.

52. Snyder, R. and Ravi B. (2005). Diamonds, Blood, and Taxes: A Revenue-Centered Framework for Explaining Political Order. Journal of Conflict Resolution, Vol 49, Issue 4, pp. 563-597.

53. UNEP (2011). Environmental Assessment of Ogoniland. Abuja: UNEP.

54. Uwem, E. (2012). Oil Revenue and Development Performance in Nigeria: Cursed By Resources, Institutions or Capabilities? British Journal of Economics, Finance and Management Sciences, Vol 6, Issue 2, pp. 64-79.

55. Wenar, L. (2016). Blood Oil: Tyrants, Violence, and the Rules that Run the World. Oxford \& New York: Oxford University Press.

56. Wood, G. (2004). Business and Politics in a Criminal State: The Case of Equatorial Guinea. African Affairs, Vol 103, Issue 413, pp. 547567.

57. Yates, D. A. (2005). 'Neo-Petro-monialism' and the Rentier State in Gabon. In M. Basedau and A. Mehler (eds.), Resource Politics in SubSaharan Africa. Hamburg African Studies 14, pp. 173-190. Hamburg: Institute of African Affairs.

58. Young, E. (1995). Third World in the First: Development and Indigenous Peoples. London, UK. 